South African Journal for Research in Sport, Physical Education and Recreation, 2011, 33(1): 81-98.

Suid-Afrikaanse Tydskrif vir Navorsing in Sport, Liggaamlike Opvoedkunde en Ontspanning, 2011, 33(1): 81-98. ISBN: 0379-9069

\title{
REFLECTIONS ON THE 1862 FOOTBALL MATCH IN PORT ELIZABETH
}

\author{
Lloyd B. HILL \\ Centre for Culture and Languages in Africa, University of Johannesburg, Johannesburg, \\ Republic of South Africa
}

\begin{abstract}
The oldest recorded football match in South Africa was played in Port Elizabeth on 24 May 1862. This article explores the available evidence for this match before moving on to a more general discussion of three broader contexts in which the match was played. These contexts are contemporary football developments in colonial Britain, the emergence of 'carrying codes' in the Cape Colony and the midnineteenth century development of sport in Port Elizabeth. Very little is known about the 1862 match in Port Elizabeth. The discussion of the match therefore serves as a pretext for a situated exploration of the $19^{\text {th }}$ century codification of 'football' which produced, inter alia, the dominant South African codes of 'rugby' and 'soccer.' Here, 'codification' involves more than the establishment of rules and clubs; it includes the association of sporting practices with other social 'codes' notably those associated with class, gender and race. In this article particular attention is given to the association of 'football' with a particular public school mediated model of masculinity. The author argues that the reason the Port Elizabeth game has gone largely unnoticed in most sporting histories is because it cannot easily be classified as 'a code' and thereby slotted into prevailing South African code historiographies.
\end{abstract}

Key words: Sociology of sport; History of sport; Sport and leisure studies; Football; Rugby; Soccer; Masculinity; Port Elizabeth

\section{INTRODUCTION}

The oldest recorded football match in the territory that is now South Africa was played in Port Elizabeth on Saturday 24 May 1862 (Eastern Province Herald, 23 May 1862). Very little is known about this match, but the evidence that has survived makes for an interesting account of an early sporting event. A key question that has inspired this article is why this game remains largely unrecorded in contemporary histories of both rugby and soccer. ${ }^{1}$ Given the paucity of information on the match, the initial narrative forms the basis of an attempt to

\footnotetext{
${ }^{1}$ Raath (2002) acknowledges the Port Elizabeth game as "the first recorded soccer match." The adult match played in Cape Town on 23 August 1862 is, however, more commonly referred to as the oldest recorded football game in South Africa: See Alegi (2004); Cruywagen (2006); Van der Merwe (2001); the Standard Encyclopedia of Southern Africa (1974); and "Historical Rugby Milestones 1860s" (http://www.rugbyfootballhistory.com /timeline1860s.htm). Dobson (1989) refers to a Cape Argus statement "that 'a game of football was to have been played at Port Elizabeth on Saturday last, for the first time". That was reported on $29^{\text {th }}$ May 1862 . But there is no record of such an historic match, which would have occurred before the first recorded match in Cape Town in August 1862."
} 
explore the social contexts in which it was played and to draw inferences about the wider historical and social significance of this match.

In this article an initial reconstruction of the 1862 event in Port Elizabeth sets the scene for a more wide-ranging exploration of three contexts in which the game was played. These contexts are: mid-19 ${ }^{\text {th }}$ century football developments in England; early football in the Cape and Natal colonies; and early sporting developments in Port Elizabeth. In the final section the analysis of the 1862 match therefore forms part of a more general discussion of the development of sport in Port Elizabeth during the second half of the nineteenth century.

While some of the inferences made about the Port Elizabeth match are tentative, the analysis is intended to provide insight into two more general social processes. The first of these is the emergence of discrete football 'codes' - notably 'Gog's football', 'rugby' and 'soccer' through their association with a stratified Anglophone education system and a particular model of public school masculinity. The second process involves the contribution that 'football' - broadly defined - made to the development of a proto-white South African identity during the second half of the nineteenth century.

\section{THE MATCH AND THE EVIDENCE}

On Friday 23 May 1862 the following announcement appeared in the "local and general" column of the Eastern Province Herald:

Foot Ball - The old game of Foot Ball is again to be revived here. We are informed that the first game of the season will be played on Saturday afternoon next, in front of the Grey Institute at three o'clock. Saturday is a capital day for such sports and the pleasure to be derived from witnessing this game will doubtless induce many of our townsfolk to be present.

The match presumably took place the next day - Saturday 24 May 1862 . A second report appeared in the Herald on Tuesday 10 June, confirming that the match was played "on the Hill in front of the Grey Institute." The "Hill" is the area now known as the Donkin Reserve, which overlooks the Port Elizabeth central business district (CBD) and harbour. The game occurred approximately three months earlier than a similar match played in Cape Town and is therefore the oldest recorded football match in South Africa. The match is all the more remarkable for the fact that - in addition to these two newspaper reports - it was recorded in the form of two team photographs. 

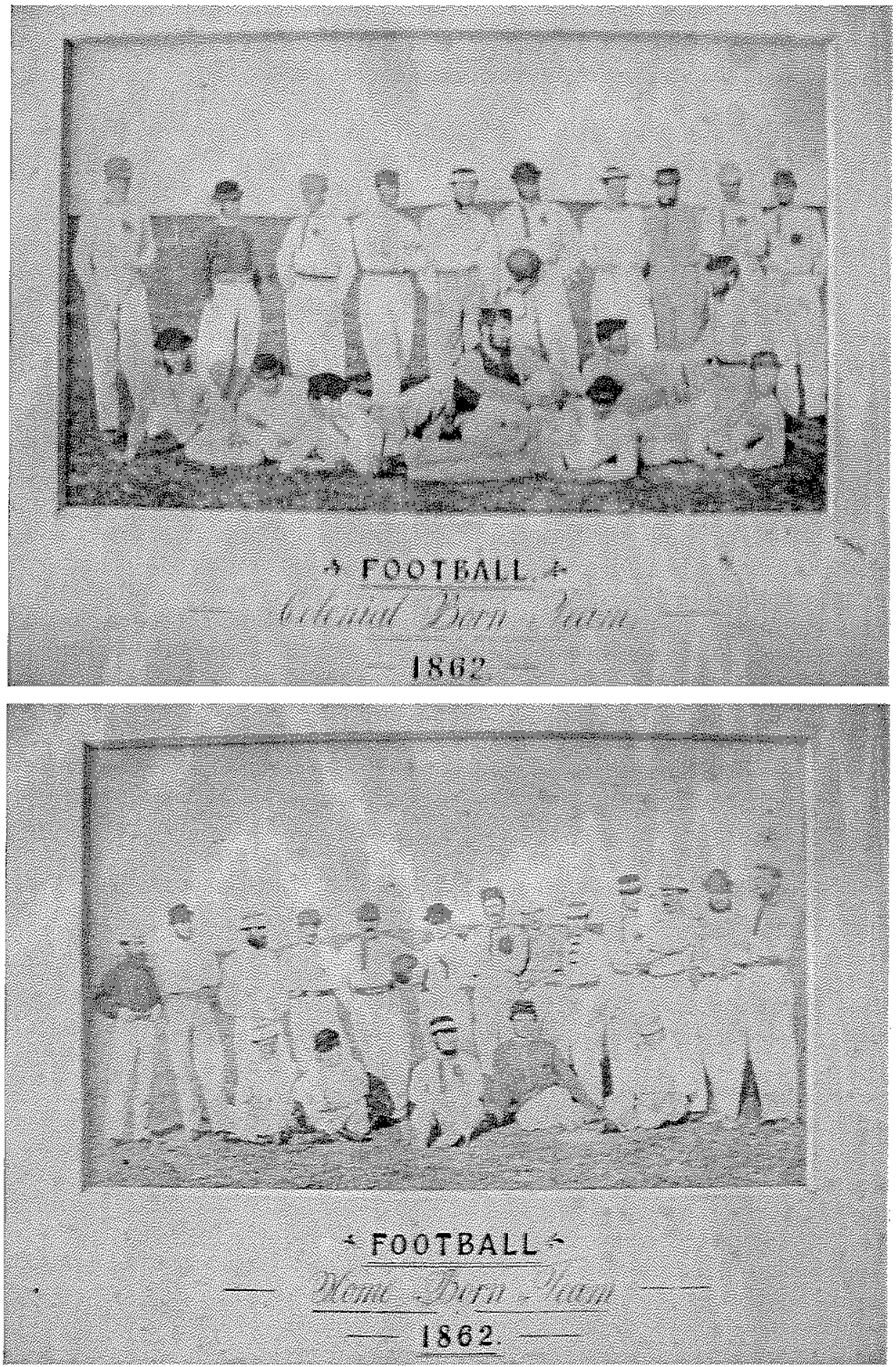
These photos ${ }^{2}$ indicate that the match involved a 'colonial born team' and a 'home born team' - each consisting of eighteen players. Here 'home' refers to England: the home-colonial pattern of team selection had previously been established in cricket.

These are the most obvious material 'facts' that have been handed down to us with respect to this match. The remainder of this article will therefore be dedicated to an examination of the gaps in the available record and to an attempt to draw inferences from what is known about the wider context of the match. The most obvious question - which will probably never be answered - is 'who won the match?' The fact that the second Herald report excludes any reference to the match, result suggests that the novelty of the sporting event outweighed the details of the game itself. This omission provides some indication of how the social significance of sport has changed over time. There are, however, two additional questions of which the answers could have particular significance for the history of South African sport. Firstly, what type of 'football' was played during this match? Do the newspaper reports and photos provide any clues (e.g., the number of players and the shape of the ball) on which to base inferences about the rules used during the match? Secondly, what is the social and historical significance of the colonial-home division evident in the match?

Answers to these questions can be inferred (albeit tentatively) from the evidence provided above, along with evidence gleaned from the wider context of this match. In the sections that follow the author explores these questions through reference to three 'levels' of this wider context: the spread of 'football codes' in the 'home country'; the introduction of 'football' to the Cape Colony; and the social significance of sport in mid-1 $9^{\text {th }}$ century Port Elizabeth.

\section{'FOOTBALL' IN THE 'HOME COUNTRY'}

The word 'football' is ambiguous today, but in 1862 it was even more so. In South Africa we tend to take for granted the now-firmly institutionalised distinction between 'rugby football' and 'association football', or 'soccer.' Moreover, we tend to follow the European convention of associating the word 'football' with 'soccer.' We must, however. bracket this association when considering the manner in which the word 'Foot Ball' is used in the account of the 1862 match presented above.

For the purpose of this brief overview of the development of 'football' in $19^{\text {th }}$ century England, the author begins with a discussion of rugby ${ }^{3}$ - the oldest of the modern 'codified variants' ${ }^{34}$ of football. In both South Africa and the United Kingdom (UK) it is widely

\footnotetext{
${ }^{2}$ The photos are housed in the South African Collection at the Port Elizabeth Main Library.

${ }^{3}$ Rugby is the oldest of the major football codes - the Rugby school rules were first published in 1845 - see "Historical Rugby Milestones 1840s" at http://www. rugbyfootballhistory.com/timeline $1840 \mathrm{~s}$.htm. The oldest codified variant of football is the Eton 'field game', with written rules dating back to 1815 (Cox et al., 2002).

${ }^{4}$ Following the work of Bourdieu, (1986: 243) 'codification' is understood to include more than just objectification in the form of written rules. Sporting codes are also manifested in institutions and in the embodied dispositions (e.g., attitudes and skills) of players. This argument has been developed in Hill (2010).
} 
believed that rugby was 'invented' by William Webb Ellis, a student at Rugby School in the 1830 s who "with a fine disregard for the rules of football as played in his time, first took the ball in his arms and ran with it." evidence $^{6}$, this belief frequently overlays two more general misconceptions about the history of football - and sport more generally. Firstly, it is often assumed that the dominant code - in this case Association football or soccer - is the oldest or 'original' variant of football. Secondly, the rugby myth betrays the more general and popular tendency to explain the development of a sport purely in its own terms, i.e. in terms of innovative practices considered 'internal' to the specific sporting code. Hence, what is now considered to be the definitive characteristics in a sport - codified as 'rules' such as 'running with the ball' or the 'offside rule' - are too conveniently explained in terms of specific sporting events or innovations (e.g., Webb Ellis' putative 'decision' to run with the ball in rugby, or - in the case of soccer - the establishment of the Football Association). What these accounts invariable miss is the more complicated history of social conflict that culminates in the adoption of a specific rule or code within a specific social context. For when we speak of the history of modern sporting 'codes' we are invariably referring to 'official games' that were, firstly, codified in writing and, secondly, recognised as legitimate / popular during or after the late $19^{\text {th }}$ century: the age in which the economics of printing and the politics of compulsory education combined to produce mass reading publics. In this context, the new football codes were not simply leisurely pursuits, they were the products of powerful new forms of social control associated with industrialised political economies.

Both rugby and soccer therefore emerged as publically sanctioned school games at a time when the British state was clamping down on popular forms of "folk football., 7 The key to making an informed inference about the nature and significance of the game played in Port Elizabeth - and other early games in the Cape and Natal Colonies - therefore lies in an analysis of the relationship between sport, geography and the class structure of British migration and settlement in southern Africa. The reference to 'Saturday sports' in the Herald extract cited above is therefore significant. The adoption of the Ten Hours Act in 1847 gave British workers more leisure time and the Saturday half-day holiday played a particularly significant role in the development of working class sport - particularly during the last two decades of the century. In South Africa, as in Britain, the institution of Saturday sport therefore formed part of a broader process of legitimating an incipient industrial society, through the common sense distinction between 'work' and legitimate forms of leisure.

The Port Elizabeth game was played more than a year before the establishment of the Football Association (FA) - at Freemason's Tavern in London on 26 October 1863. It took

\footnotetext{
${ }^{5}$ These words are recorded on a plaque at Rugby School, which was erected in 1900 (Collins, 2006).

${ }^{6}$ At Rugby running with the ball was first officially allowed in the early 1840 s - see "Historical Rugby Milestones 1840s" at http://www.rugbyfootballhistory.com /timeline1840s.htm. The Webb Ellis myth is attributed to an account provided by another old boy, Matthew Bloxam in 1877 (Collins, 2006).

7 The UK Highways Act (1835) banned the playing of [folk] football on public highways (Collins, 2006). Bragg (2006: 96) notes how the land enclosures in England crowded out folk football and prepared the field, so to speak, for the modern codes.
} 
the self-proclaimed governing body another month to compose a set of rules, eventually inspired by those used at Cambridge University. These 'rules' nevertheless constituted a 'broad transcription' of the wide range of verbal agreements that were typically reached before kickoff in actual football matches. The Rugby-Soccer split was effectively institutionalised in 1871, when 'handling clubs' established the Rugby Football Union. The words 'rugger' and 'soccer' (a truncation of 'association') emerged some time after this date, as university slang terms for both the players and their chosen football codes. Prior to the 1870 s the FA's ability to enforce a standard was limited by organisational weakness and the 'fluid state' of rules used during this period (Collins, 2006). Before 1863, the key social division would therefore have been between the growing number of middle class school boys and ex-school boys playing hybrid 'kicking', 'handling' and 'carrying' codes and working class communities playing numerous forms of 'folk' or 'mob football.' During the $19^{\text {th }}$ century a number of events conspired to promote the development of specific 'codes' - first rugby and then soccer - as dominant standardised forms of football.

First and foremost among these was the influential role that Rugby School played as a model of public school reform. Rugby football owes its early distinction not to William Webb Ellis, but to the well-known headmaster of the school, Thomas Arnold. Arnold was not a sports enthusiast, but his educational reforms established Rugby as the leading public school in $19^{\text {th }}$ century England. Chief among these were the introduction of French (a prelude to the teaching of 'modern languages' and the decline of Latin and Greek) and national history to the school curriculum (Gamble, 2007). It was Arnold's successors that established Rugby football - alongside cricket - as a new type of 'sport' ${ }^{8}$ through its association with 'athleticism', and a new ideal of masculinity; the public school educated gentleman. While Eton, Harrow and other public schools codified their own versions of 'football', it was the Rugby game that was subsequently established as the football code of choice among imperial

8 'Sport' is a relatively new introduction to the English vocabulary (c.1500), deriving from the older French import 'disport' (1303), which via 'se desporter' (Old French, 'to behave oneself' - cf. older sense of the English word 'deport') derives ultimately from the Latin 'portare' ('to port' or 'to carry') (Partridge, 1958). 'Disport' shares with Old English word 'game' ('gamen', 1225) an early sense akin to contemporary usage - a 'diversion' or 'pastime.' The modern sense of 'sport' as "activities involving physical exertion and skill, especially competitive activities governed by rules" is first attested in 1793, where it refers to cricket. This new 'athletic' sense may have developed through association with the classical Latin 'ludus' ('play') and, more specifically, the public games of ancient Greece, such as the Olympic Games ('ludi Olympii'), which included various athletic contests, wrestling, boxing, and horse racing. See Oxford English Dictionary Online, Oxford University Press, 2009.

${ }^{9}$ Athleticism is defined by Mangan (2008: 607) as "physical exercise ... taken considerably, and compulsorily, in the sincere belief of many [or the time], however romantic, misplaced or myopic, that it was a highly effective means of inculcating valuable instrumental and impressive educational goals: physical and moral courage, loyalty and cooperation, the capacity to act fairly and to take defeat well, the ability to both command and obey." 
and colonial authorities. Arnold's students - particularly those who became teachers ${ }^{10}$ - were instrumental in the dissemination of the Rugby game. By far the most influential of these students was Thomas Hughes, who published Tom Brown's Schooldays in 1857. This novel celebrated school life at Rugby during the 1830 s and its description of the Rugby game played a significant role in the establishment of rugby as an elite school game in many parts of the British Empire (Collins, 2006; Taylor, 2008). The public school sports ethos was subsequently extended to higher education. Hughes' sequel novel - Tom Brown at Oxford (1861) - contains the following exchange:

'Try cricket, for instance. The players generally beat the gentlemen, don't they?' 'Yes, but they are professionals' (Oxford English Dictionary Online, 2009).

Here the use of 'gentleman' as a gender code is associated with two distinct senses, both attributed to upper/middle class boys emerging from public schools and - more often than not - gaining access to Oxford or Cambridge. The first is the sense of "a man of superior position in society, or having the habits of life indicative of this"; while the second - associated with cricket as far back as 1806 - is sports-specific, juxtaposing the 'amateur gentleman' with the 'professional' and (initially) working class 'player', who receives remuneration (Oxford English Dictionary Online, 2009).

The second trend was therefore the emergence of post-school football, based on rules that were initially codified by the public schools. At this level the Rugby game lost ground to the codes originating at public schools in the South East of England. Particularly significant in this respect were the Cambridge and the Sheffield rules. The 'Cambridge Rules', first published in 1848, constituted the first inter-public school standard for former public schoolboys entering the university. The Sheffield rules - based on games played at Eton and Harrow - were first published in 1856 (Cox et al., 2002) and provided a powerful early stimulus for the establishment of soccer-like football clubs in the North of England. Religious institutions and (initially Anglican) teacher training colleges - beginning with St Peter's College, founded in Birmingham in 1850 - also played an important role in popularising proto-football codes among the working class. During the 1880 s these colleges were particularly instrumental in the growth of working class soccer (Mangan \& Hickey, 2008).

A third key factor that influenced the development of standardised football codes was the industrial production of sporting equipment - beginning with the ball. Changes in the shape of the ball had both a technical and a symbolic significance, which sharpened the distinction between the codes and shifted the advantage - in terms of popular recognition of 'the round ball' - decisively in favour of association football. The original 'folk' football - a pig's bladder encased in leather - was neither round nor pronouncedly oval in shape and early balls varied considerably in terms of size, weight and shape. This changed with the industrial production of rubber. In 1854 the American inventor, Charles Goodyear, won a gold medal at the international exhibition in Paris for his vulcanized rubber football. Round rubber-cored balls would subsequently "change the shape of Golf, Tennis and Football more than any other

${ }^{10}$ Hilton College became the main bastion of school rugby in Natal after the arrival of its second headmaster, who was a former pupil of Rugby School. See http:/www.hiltoncollege.com/history /index.htm. 
single factor" (FIFA Museum Collection, 1996). The industrial production of rubber football inner-tubes began in the town of Rugby in 1862 (Hill, 2010: 17). The mass production of standardised round and oval balls provided a major impetus to the crystallisation of distinct football codes, defined both in terms of fixed 'rules' and the increasingly distinct, but variable, sets of embodied 'strategies' that emerged following the standardisation and marketisation of sporting fields and equipment.

If the small-scale industrial production of rubber 'footballs' only began in 1862 , it seems highly unlikely that one of these balls would have made it to Port Elizabeth in time for the May football match. The ball depicted in the photos is therefore almost certainly a pig's bladder and can therefore provide no clue to the nature of the game played. Neither can the size of the teams provide us with an indication of the rules, as most of the early rule-sets did not specify team size. For reasons discussed below, the Port Elizabeth game more than likely complied with rules imported directly from 'the home country.' The problem is that before 1862 there were far too many variants of football in England. A second line of enquiry is therefore to compare the Port Elizabeth game with other early football matches in South Africa.

\section{'CARRYING CODES' IN THE CAPE COLONY}

As in the 'home country' the diffusion of modern sporting codes in South Africa was mediated by geographical and social class divisions. The racial divisions that would become so prominent in $20^{\text {th }}$ century South African sport were built on a process of 'white' social closure that followed the gradual transcendence of these earlier divisions. Sport played a significant role in bridging these 'intra-white' divisions and, with respect to 'football', there appear to have been two principle early 'modes' of diffusion: elite English (and Iater Afrikaans) education and predominantly working class British immigration. As in North America and the southern dominions (Australia and New Zealand) elite colleges (and later universities) played an important role in spreading Rugby-inspired 'carrying codes' - 'Gog's game' and subsequently rugby. Military regiments, on the other hand, were instrumental in propagating Association football, particularly in Natal and the South African Republic between 1880 and 1910 (Alegi, 2004).

The 'carrying codes' emerged in Cape Town and developed through their association with elite secondary and higher education. Collins (2009: 16) notes the early historical significance of Arnoldian education in South Africa:

In South Africa, initially among English speakers, the Arnoldian model of public school life was adopted completely by white middle-class educators and sports enthusiasts. Although the Winchester School code had been originally played in Cape Town, seen as the cradle of rugby, this was abandoned in the 1870s and rugby quickly came to dominate white sporting culture. It was through elite schools such as Old Diocesans, Bishops and Hilton College that rugby acquired a social significance and the means to spread throughout white South African society.

The status of Rugby within a 'white sporting culture' nevertheless took some time to develop and this process was not evenly distributed. In the remainder of this article it is argued that 
the 1862 adult games played in Port Elizabeth and Cape Town reflect an early manifestation of this uneven development and therefore provide insight into the early social role of sport in two broad processes: the construction of a domestic 'white identity' and the stratification of education, in terms of gender, class and race.

While the Port Elizabeth match referred to above is the oldest individual South African game on record, the earliest football games were played in Cape Town. The first known 'variant' of football was played at South Africa's second oldest school, Diocesan College or Bishops. Bishops was the first Anglican school to be established in South Africa and this fits a more general colonial pattern: Anglican educational institutions were influential in propagating both specific football codes and the ideology of 'athleticism' that underpinned them (Mangan \& Hickey, 2008). In 1859 Canon George Ogilvie became headmaster of the Diocesan College, where he subsequently introduced a variant of football that he learnt during his studies in England. This game formed the basis of an early inter-school rivalry between Bishops and the rival South African College (SACS). Matching a pattern evident in many parts of the UK, the rules introduced at Bishops spread first to neighbouring schools and then to senior clubs (Babrow \& Stent, 1963). The relative fluidity of the rules used during these early games - notably with respect to team size - has, however, also been noted (Van der Merwe, 2001).

The first recorded adult match in Cape Town took place on Saturday 23 August 1862 - long before the establishment of formal adult football clubs. ${ }^{11}$

Foot-ball - We are happy to find that this fine old English school game has been introduced among us. On Saturday next sides consisting of fifteen officers of the army and a like number of gentlemen in the civil service will open the Ball with a game on the race-course at Green Point. Of course this example will be speedily followed and we shall have foot-ball treading closely on the kibes of cricket and our other imported manly games (Cape Argus, 21 August 1862).

This match employed Gog's rules and there is a record of a subsequent match played between seniors and students from Bishops, which was won by the students. ${ }^{12}$ A comparison of this report with the extract from the Eastern Province Herald - cited above - reveals the extent to which the Cape Town match was associated with education and an emerging educated class indicated that these men were 'gentlemen.' Firstly, while the initial sentences of both extracts are remarkably similar, the Argus refers more specifically to "an old English school game" (my italics), which reflects a recognition of the fact that this match was based on rules imported from English public schools.

\footnotetext{
${ }^{11}$ The first adult club, the Hamilton Football Club, was established in 1875 and was followed, a year later, by the Villager Football Club (Babrow \& Stent, 1963). A football club called 'Roslyns' was established in 1881 or 1882 in a region established by freed slaves, which since 1867 had been known 'District Six' (Booley, 1998).

${ }^{12}$ A record of these games can be found in the Cape Times, 10 April 1937 and reproduced on the Bishops website (http://www.bishops.org.za/info/museum/sport.asp).
} 
Secondly, the reference to "gentlemen in the civil service" is significant in two respects. In Cape Town during the early 1860 s the word 'gentleman' would have carried the English association with education and elevated position. The reference to the civil service also indicates that these men were well educated. The Board of Examiners of Candidates for Government Service (BECGS) had been established 12 years earlier, for the purpose of training civil servants. This was the only form of post-secondary education available until 1858, when the more general Board of Public Examiners in Literature and Science (BPELS) was established. This Board was subsequently replaced by the University of the Cape of Good Hope (UCGH - 1873). Both the BPELS and the UCGH were examining institutions, responsible for accrediting the post-secondary education provided at elite high schools. In terms of the Higher Education Act of 1874 these schools became known as 'colleges'; they included SACS and Bishops in Cape Town and - crucially for the subsequent diffusion of rugby - the Stellenbosch College. The Grey Institute in Port Elizabeth - referred to in the Herald extract cited above - also functioned as a college, albeit for a brief period (1875 1885). The civil service also produced the first leisure club - the Civil Service Club - in 1861 (Van der Merwe, 2001). In the Argus report on the match the publication of the names of the civil service players is clearly an indication of status. The civil service team included John X. Merriman (later Prime Minister of the Cape Colony) and G.C. Bayne (later resident magistrate of Port Elizabeth ${ }^{13}$ ).

The 1862 Cape Town game therefore employed an established school code and, moreover, was played within the context of a relatively powerful public school system and an emerging higher education tradition. ${ }^{14}$ The Bishops game was for this reason the most influential variety of football in South Africa prior to the institutionalisation of rugby and soccer in the $1880 \mathrm{~s}$ and $1890 \mathrm{~s}$. Given the difficulty associated with the reconstruction of events during this period, it is perhaps understandable that this code has been cited as the earliest example of both rugby (Difford, 1933, Herbert, 1980) and soccer (Alegi, 2004) in South Africa. Gog's game is commonly referred to as the "Winchester code" in South African sporting histories 15 , but Ogilvie also studied at St Andrew's College. The Bishops game allowed some running with the ball and has therefore been described as a 'polygenetic game' (Babrow \& Stent, 1963). Indeed, enthusiasm for running with the ball has been cited as a reason for the eventual switch to Rugby. ${ }^{16}$ Coming seven years after the establishment of the English Rugby Football Union, it nevertheless seems more likely that the switch reflected the growing status of rugby in the colonies and the cultural power of English settlers who had recently arrived at the Cape. A particular impetus for rugby came in the form of William Milton - an ex-England

13 Interview with Margaret Harradine, retired archivist in the Africana section of the Port Elizabeth Main Library, 23 September 2009.

${ }^{14}$ In addition to his role at Bishops, Ogilvie also served as a member of the BPELS and as vice-chancellor of the University of the Cape of Good Hope. He is described as "a much travelled member of that breed of muscular Christians who figured so prominently in nineteenth century British education" (Boucher, 1973).

${ }^{15}$ See, for example, "100 years of South African rugby: Part one", http://www.irb.com/news media/features/newsid=278026.html.

${ }^{16}$ Babrow and Stent (1963) comment that "the immediate appeal of rugby lay in the wider freedom it gave to handling." 
rugby player - who convinced the Hamilton Club to switch to rugby in 1878. A year later, after a brief internal feud, the rival Villagers Club followed suit.

In South Africa, as in the UK, the crystallisation of the rugby-soccer split took place in the 1870 s. The relatively few games played in the 1860 s would therefore more than likely have been hybrid variants, combining practices associated with contemporary rugby and soccer with numerous other practices - such as 'hacking' - that have subsequently been banned in both codes. In Cape Town the rules introduced at the Diocesan College became the dominant code at both school and adult club level. As in the UK, the elite schools initially resisted the introduction of a new standard. ${ }^{17}$ By 1970 these rules were also being used by schools in Natal, before being replaced by the RFU and FA codes some years later (Herbert, 1980). The earliest recorded game in the Natal Colony was played on the market square in Pietermaritzburg between the City and the Garrison on 26 September 1866. A spectator commented that "the rules were systematically disregarded by both sides through the whole game" (Hattersley, 1938). This statement begs the question "which rules'? Could this game and the earlier game played in Port Elizabeth have been based on the rules used in Cape Town? This is possible, but in Port Elizabeth it seems unlikely, for reasons explored in the next section.

\section{THE EARLY SIGNIFICANCE OF SPORT IN PORT ELIZABETH}

As a preface to a discussion of early sport in Port Elizabeth, it is worth considering three events that fundamentally changed the political context within the eastern region of the Cape Colony. The first of these was the war of Mlanjeni - more commonly known as the Eighth Frontier War (1850-1853). This war marked the beginning of the decade in which Xhosa independence was finally lost. Together with the Nomgqawuse cattle-killing of 1856-1857, this war effectively crushed the political economy of the Xhosa and prepared the ground literally speaking - for a new wave of British immigration. By 1857 the Cape Colony was "prosperous as never before" and following the passage of Act 8 through the Cape Parliament, $£ 50000^{18}$ was allocated to facilitate British immigration to Cape Town and Port Elizabeth (Bull, 1991). Between 1857 and 1867 about 12000 immigrants settled in the Cape Colony, most of whom where drawn from the ranks of skilled labour and artisans. The significance of this figure needs to be seen in the context of the time. Prior to the immigration Port Elizabeth was a village with just 4000 people, compared with a population of about 25000 in Cape Town (Bull, 1991). Given the predominantly working class status of post1820 immigration to Port Elizabeth, this new wave of immigrants had a far more profound affect on the social structure of the settlement in Algoa Bay. Sport would appear to be one of the areas where this impact was particularly evident.

\footnotetext{
${ }^{17}$ SACS and the Diocesan College switched to rugby in 1884 - a year after the establishment of the Western Province Rugby Football Union. This is also the year of the first intercollege rugby match between SACS and Stellenbosch College (Babrow \& Stent, 1963). Collins (2009) notes that the Rugby School joined the Rugby Football Union two decades after it was founded.

${ }^{18}$ This figure pales in comparison to the $£ 2000000$ the British spent on the Eighth Frontier War (Bull, 1991).
} 
In the Herald extract cited above, the reference to football being 'revived' in Port Elizabeth suggests that the match formed part of a broader pattern: the sporadic nature of sporting events at this time. While there is no known earlier reference to football, the pattern had already been established in cricket. The earliest reference to cricket in Port Elizabeth is a match played between two local teams - the "Marrowbones" and the "Sans Culottes" - in 1843 (Grahamstown Journal, 28 December 1843). Attempts were made to establish a cricket club in 1847, 1849 and 1856 . These early efforts did not prove sustainable and on 1 February 1859 the re-establishment of the club was announced in the Eastern Province Herald:

The Club, we have been informed, numbered over forty members and it would indeed be discreditable to our prestige as the descendants of "The Sons of Merrie England" were it now to languish for the want of support and attendance on "The Field!" (Eastern Province Herald, 1 February 1859).

The football match of 1862 would therefore seem to confirm this pattern of sporadic early sporting events that preceded the establishment of codes and clubs. This pattern is probably best explained in terms of the tendency for immigrants to use Port Elizabeth as a transit point en route to the various agricultural settlements in the hinterland. As the post- 1857 immigrants were predominantly skilled workers, the 1860 s witnessed not simply the rapid growth of 'a town', but also the emergence of new patterns of settlement and social stratification. In July 1860 the passage of the Port Elizabeth Incorporation Bill through Parliament gave Port Elizabeth the status of a borough, with an elected mayor and town council. Prior to this Port Elizabeth had been governed by a Board of Commissioners. In March of the previous year this Board had granted the reconstituted cricket club two acres of land "at the top of a steep escarpment, on the outskirts of the village" (Levey, 1959). This land would subsequently become known as St Georges Park. There is therefore a clear sense in which the geographical elevation of sporting fields coincided with the gradual social elevation of 'sport' as means of social stratification in early Port Elizabeth, as the subsequent discussion of education will show.

By 1862 cricket was already established and football (ultimately rugby) would follow, as a seasonal alternative, in its wake. It is, however, interesting to note how long this process took. The next reference to football in the Herald appears on 14 May 1887, when the "opening of the football season" was announced. The article notes that the "newly-formed Crusaders Club - following Rugby Union Rules - played its first game." Curiously, the article also notes that "in 1881 the Council gave permission for the club to share the Port Elizabeth cricket club ground" (my italics). But was this the same club? Parker (1897) notes that the association game was played in Port Elizabeth "as far back as 1881" and that Wanderers Association Football Club was established "fifteen years ago", which is to say in 1882. Does this mean that Crusaders or some other club was established in 1881, initially as an association football club? The water is muddied somewhat by Levey's (1959) reference to an 1889 request that "a rugby club named Crusaders" be allowed to use the cricket ground during the winter season.

The details are sketchy, but a general pattern is evident. Adult rugby was established in PE in the late 1880s, some years after the establishment of rugby in Cape Town (1883-4). Association football, it would seem, made an early debut (1881-2) during a period coinciding with the establishment of the Natal Football Association (1882) and the rapid growth of the 
association code in the Natal Colony. But in Port Elizabeth the association code was weak and was eventually re-established in 1996, the year in which the Eastern Province Football Association was founded and three new clubs were established (including a newly formed Wanderers Club) (Parker, 1897; Trader, 2002). As in many other parts of the country, the rugby-soccer split can therefore be traced back to the $1880 \mathrm{~s}$. This period coincided with the decline of Gog's game in the Cape Colony and a new influx of British soldiers - prior to the first Anglo-Boer War and the Anglo-Zulu War - who played a significant role in promoting the association game (Alegi, 2004). In Port Elizabeth, however, the code split was difficult to pinpoint and does not seem to have been preceded by a hybrid code. The main reason for this would seem to be the contrasting status of education in the eastern and western regions of the Cape Colony.

A significant aspect of the May 1862 game is that it was played "in front of the Grey Institute" - that beyond this fact there is no known institutional connection between the match and the Grey Institute, or education more generally. Having opened its doors in 1859, the Grey Institute ${ }^{19}$ was not the first school $^{20}$ in Port Elizabeth, but it was soon established as the most prestigious educational centre in the town. The opening of the Grey Institute marked the beginning of educational stratification in two significant senses. Firstly, it was established on 'the Hill' above the town, which in 1859 was not very accessible. The Hill, in contradistinction to the 'town below' gradually established a reputation as the fashionable quarter of the town (Bodill, 1984). That the new school on the Hill catered to relatively wealthy families is evident from the fact that the Grey Institute offered a separate education facility for the poor in the Bethel, a chapel for seamen that was opened eight months after the school on the Hill (Harradine, 1995). By 1862 the Grey Institute would have been one of very few buildings on the Hill and the geographical class distinction would therefore not have been very well established. ${ }^{21}$ Moreover, there is no known evidence to suggest that sport played any part in the curriculum at this time.

The second form of stratification involved the introduction of secondary and tertiary education in Port Elizabeth. As noted earlier, in Cape Town the crystallisation of discrete sporting codes was closely associated with the spread of literacy and the growth of secondary/tertiary education. In this trend Port Elizabeth lagged behind the other two colonial ports, as well as Grahamstown - the dominant centre on the eastern fringe of the Cape

19 Technically the Grey Institute - or the school on 'the Hill' - was the first of a series of Grey institutions established in terms of Act No. 6 of 1856, "An Act for Regulating the Public Schools of Port Elizabeth upon the Grey Foundation" (Young, 2006). Two additional junior schools were established in North End (1861) and South End (1875) (Harradine, 1995).

${ }^{20}$ The first request for a school in Port Elizabeth came in 1824. In 1832, the Rev. Francis McCleland advertised his intention to open a day school, attached to St. Mary's Anglican Church. In 1841 a new teacher, John Paterson, arrived in Port Elizabeth and established the Senior Free Government School - the school was closed in 1866. A Diocesan Grammar school is believed to have been established in 1853, closed in 1859 and revived a number of times during the course of the eighteenth century (Harradine, 1984).

${ }^{21}$ Interview with Margaret Harradine, 23 September 2009. 
colony. The Grey Institute was associated with 'undenominationalism', an educational reform movement that developed during the second half of the $19^{\text {th }}$ century and played a significant role in the establishment of higher education in South Africa. Thus, in the same year that the Grey Institute opened its doors, the local Diocesan Grammar School was forced to close (Harradine, 1984: 17). The association of undenominationalism and written examinations dates back to the establishment of the University of London, which served as a model for the Cape higher education system - beginning with the BECGS in 1850 (Boucher, 1973). By 1862 this trend had spread to Port Elizabeth. Three months before the football match in question the Eastern Province Herald announced the introduction of "examination by written papers", which was held to be "much more thorough and searching than any viva voce examination could be" (Eastern Province Herald, 17 January 1862). This came in the wake of the establishment - in Cape Town - of the Board of Public Examiners in Literature and Science (BPELS). The establishment of this board marked the beginning of higher education certification by written examination in South Africa. Students at the Grey Institute and related colleges countrywide could sit exams and obtain first, second and third class certificates, which were based on the MA, BA and Matriculation examinations of the University of London respectively (Boucher, 1973). But in Port Elizabeth demand for these qualifications was extremely limited: in 1864 three candidates at the Grey Institute sat and failed the second class maths section (Rautenbach, 1995). In 1874, a year after the promulgation of the Higher Education Act, the first matriculation examinations were held at the Grey Institute (Young, 2006). A year later the school was accredited as a higher education 'college.'

By 1885 the effort to turn the Grey Institute into centre for higher education was judged to have failed. The end of the college system came with the appointment of a new headmaster and the introduction of the English public school system (Young, 2006). While the first sports day was held in 1867 , it was the revival of the sports day in 1893 , within the context of the adoption of the public school model - defined in terms of single sex education ${ }^{22}$ and boarding hostels $^{23}$ - that marks the beginning of school football and the more general institutionalisation of athleticism in Port Elizabeth. ${ }^{24}$ Both rugby and soccer were introduced soon after this date, with soccer said to have "ousted rugby" by 1906 (Young, 2006). This was short-lived, however, as rugby established itself alongside the other curriculum sports: cricket, tennis, athletics and swimming. Mirroring a broader 'national' trend, rugby was established as as "the patrician football code of South Africa" (Gibson \& Pickford, 1906).

${ }^{22}$ Except for the early years - referred to as 'mixed infants' - single sex education was an ideal of the public school system. It is noteworthy that the introduction of sport at the Grey Institute coincides with the institution of separate education for girls. In 1893 the Diocesan Grammar School closed again and was replaced by a Diocesan School for Girls (Harradine, 1984). A year later Collegiate - the sister institution to the Grey Institute - opened its doors. 1906 was the last year that girls attended the Hill school (Young, 2006).

${ }^{23}$ The first 'proper' boarding house was established in 1911 (Young, 2006).

24 Athleticism would seem to have peaked in the early twentieth century, when Rector William Archer Way is said to have "over stressed sport" in the selection of staff. His successor subsequently dismissed a number of teachers "who were not worth their salt" (Young, 2006). 
The key difference between the two adult games played in Port Elizabeth and Cape Town in 1862 therefore relates to their association with education and the educational philosophy of athleticism. The Cape Town game was the manifestation of a football 'code' introduced to Cape Schools and developed within the context of an emerging elite education system and a new educational philosophy - athleticism. In contrast, we know almost nothing about the nature of the game played in Port Elizabeth. The profile of education in Port Elizabeth was quite unlike that of Cape Town, where the elite status and early rivalry of SACS and the Diocesan College underpinned the diffusion of Gog's football. Given that the Port Elizabeth match occurred some months before the first recorded adult match in Cape Town, it seems very unlikely that the game played was based on Gog's rules. It rather seems reasonable to assume that the game was based on rules imported by British immigrants newly arrived in the town. There is no evidence of football codification in the $1860 \mathrm{~s}$; the establishment of distinct codes in the 1880s and 1890s coincided with the introduction of an English public school tradition and the concomitant commitment to athleticism. During this period it is difficult to establish a causal relationship between school and adult football. It seems very likely that both levels were influenced by powerful trends in Cape Town, Durban and Johannesburg. Developments in the major urban centres also provide clues to the social significance of the 'colonial' versus 'home-born' division evident in the Port Elizabeth match. Sport played a significant role in fostering a domestic sense of 'whiteness' and the Port Elizabeth 'colonial' side would seem to be the first white proto-national distinction of this kind to be manifested in football. The Anglophone colonial sporting environment would subsequently be extended to include 'white Dutch speakers.' This process began in the Cape, where Babrow and Stent (1963) note the "Colonial-Born versus Mother Country" competitive ethos that preceded the introduction of football to Stellenbosch.

Competition between proximate towns also played a significant role in bridging the language divide, particularly after the construction of railways. The linking of Port Elizabeth and Uitenhage - in 1873 - was therefore significant, but not as significant as the sporting rivalries that developed between Cape Town and Stellenbosch, Durban and Pietermaritzburg and Johannesburg and Pretoria. Railways did, however, have another important role to play in the development of a colonial-born white identity in Port Elizabeth. Bull (1991) observes that the Ninth and final Frontier War in 1877 and "the increasing number of blacks employed on the railways had an adverse effect on immigration." British immigration resumed in the 1880 s, but this coincided with the gradual in-migration of Xhosa workers. The desire to contain 'them' resulted in the Native Reserve Location Act of 1902, which established New Brighton (in Port Elizabeth) and Ndabeni (in Cape Town) as the first urban 'locations' (Mamdani, 1995). The frontier had entered the city.

\section{CONCLUSION}

In this article the author has explored the evidence available for the match played in Port Elizabeth on 24 May 1862. While there is no doubt that the match took place and that it is consequently the oldest recorded 'football' game in South Africa, the key questions that remain relate to its wider sporting and social significance. The author's analysis has sought to interpret the available evidence by way of a discussion of sporting trends in the wider regional and colonial environment. 
The surviving evidence provides no indication of the type of 'football' played on this occasion. Given the unstandardised nature of 'football' during this period, the evidence provided by the team photographs (e.g., ball shape and team size) therefore provide no clues to the rules used in this game. It is nonetheless highly probable that the game was a 'hybrid' variant - combining rules associated with the subsequent 'codes', notably 'rugby' and 'soccer' - imported by the 'home born' players or other recent British immigrants to Port Elizabeth. A variant in this sense is, however, not 'a code.' 'Codification' involves more than the establishment of rules and clubs; it also refers to the institutionalisation of 'a sport' through its association with other social institutions and conventions. Particular attention was given to educational institutions. As in the UK, the crystallisation of distinct South African football codes formed part of a broader process: the introduction of an increasingly stratified Anglophone education system in which a new educational philosophy called 'athleticism' emphasised the importance of specific sports in the training of relatively wealthy boys. The discussion of football codification in the Cape Colony therefore paid particular attention to the contrasting status that sport enjoyed in the socially stratified education systems of Cape Town and Port Elizabeth during the $19^{\text {th }}$ century. At the heart of the matter is the process of codification that gave rise to distinct football codes: 'Gog's football', 'rugby' and 'soccer.

While the 1862 game in Port Elizabeth has been cited as the earliest manifestation of 'soccer', there is no evidence to support this claim. The Port Elizabeth game was played a year before the establishment of the Football Association and a good ten years before the soccer/rugby distinction became socially significant in the UK and South Africa. It is possible that this match was based on 'Gog's game' (or the Winchester code), which had been introduced to schools in Cape Town three years earlier, but this seems very unlikely. The Port Elizabeth match therefore does not fit into the dominant narrative of rugby codification that has traditionally focused on the western region of the Cape Colony. It is within the context of the early educational dominance of this region - and the wider educational significance of 'carrying codes' - that Gog's game is commonly interpreted as the predecessor to rugby in South Africa.

In this article it was argued that the key difference between the adult football games played in Port Elizabeth and Cape Town in 1862 relates to their contrasting positions within the emerging educational class structure of the Cape Colony. The Cape Town game manifested a code - Gog's game - and as such represented continuity with elite school football and the philosophy of athleticism that underpinned it. In Port Elizabeth the post-1857 arrival of a new artisanal class probably explains the growth in the popularity of sporting events, but in a predominantly working-class town it would take another 30 years before football was institutionalised as 'a sport.' This process coincided with the introduction of the English public school model at the Grey Institute and the concomitant commitment to athleticism. And it is in this context (c. 1880) that 'rugby' and 'soccer' first began to emerge as distinct adult sporting codes in Port Elizabeth.

In a rapidly growing English settler town, the 1862 'game on the Hill' probably manifested the growing influence of the UK - vis-à-vis Cape Town - on life in Port Elizabeth. The game also provides evidence of what, at the time, was a more widespread social cleavage: the division between 'home' and the 'colonial-born' settlers of British descent. This is therefore the earliest football manifestation of a more general trend: the significant role played by sport 
in fostering social interaction and gradual social closure among 'white' immigrants. The game is therefore more interesting as a socially situated study of the emergence of 'sport' - as opposed to 'a sport'. The fact that the Port Elizabeth game cannot easily be classified as 'a code' and thereby slotted into prevailing South African code historiographies is no doubt an important reason for the relative obscurity of this game in the existing literature. The relatively unknown Port Elizabeth match is therefore "the dog that didn't bark" in the history of South African football (both Rugby and Association), which is to say a frequentlyignored event that tells us more about the early social significance of a relatively amorphous 'football' than it does about the genealogy of a specific football code.

\section{REFERENCES}

ALEGI, P. (2004). Laduma! Soccer, politics and society in South Africa. Pietermaritzburg: University of KwaZulu-Natal Press.

BABROW, L. \& STENT, R.K. (1963). The varsity spirit - the story of rugby football at the University of Cape Town. Cape Town: Johnston \& Neville.

BODILL, T.S. (1984). Knockfierna. Looking Back. The Journal of the Historical Society of Port Elizabeth, 101-110.

BOOLEY, A. (1998). Forgotten heroes: History of black rugby, 1882-1992. Cape Town: Manie Booley Publications.

BOUCHER, M. (1973). Spes in arduis - a history of the University of South Africa. Pretoria: University of South Africa.

BOURDIEU, P. (1986). The forms of capital. In J.G. Richardson, Handbook of theory and research for the sociology of education. New York, NY: Greenwood Press.

BRAGG, M. (2006). 12 books that changed the world. London: Hodder \& Stoughton.

BULL, E. (1991). Aided immigration from Britain to South Africa - 1857 to 1867. Pretoria: Human Sciences Research Council.

COLLINS, T. (2006). Rugby's great split - class, culture and the origins of rugby league football. New York, NY: Routledge.

COLLINS, T. (2009). A social history of English Rugby Union. Abingdon: Routledge.

COX, R., RUSSELL, D. \& VAMPLEW, W. (Eds.). (2002). Encyclopedia of British football, London: Routledge.

CRUYWAGEN, D. (Ed.). (2006). The badge - a century of the Springbok emblem, Cape Town: South African Rugby Union.

DIFFORD, I.D. (1933). The history of South African rugby football. Cape Town: The Speciality Press of South Africa.

DOBSON, P. (1989). Rugby in South Africa - a history 1861-1988. Cape Town: South African Rugby Board.

FIFA MUSEUM COLLECTION (1996). 1000 years of football. Berlin: edition q.

GAMBLE, R.M. (Ed.). (2007). The great tradition - classic readings on what it means to be an educated human being, Wilmington: ISI Books.

${ }^{25}$ The well-known reference is to "Silver Blaze", one of Arthur Conan Doyle's Sherlock Holmes mysteries. The phrase is now commonly used to indicate the potential explanatory significance of 'non-events' or rather, minor events misrecognised as insignificant. 
GIBSON, A. \& PICKFORD, W. (1906). Football and the men who made it (South African Edition). Cape Town: D.E. McConnell and Company.

HARRADINE, M. (1984). The Diocesan Grammar School, Port Elizabeth. Looking Back. The Journal of the Historical Society of Port Elizabeth, 15-19.

HARRADINE, M. (1995). Port Elizabeth - A social chronicle to the end of 1945. Port Elizabeth: E.H. Walton Group.

HATTERSLEY, A.F. (1938). Pietermaritzburg panorama: A survey of one hundred years of an African city. Pietermaritzburg: Shuter and Shooter.

HERBERT, A. (1980). The Natal Rugby story. Pietermaritzburg: Shuter \& Shooter.

HILL, L. (2010). Football as code: The social diffusion of 'soccer' in South Africa. Soccer \& Society, 11(1-2): 12-28.

LEVEY, S.H.W. (1959). The hundred years: 1859-1959. Port Elizabeth: Port Elizabeth Cricket Club.

MAMDANI, M. (1995). Citizen and subject - contemporary Africa and the legacy of late colonialism. Cape Town: David Philip.

MANGAN, J.A. \& HICKEY, C. (2008). Early inspiration: athleticism and colleges. Soccer \& Society, 9(5): 607-631.

PARKER, G.A. (1897). South African sports. London: Sampson Low, Marston, and Company.

PARTRIDGE, E. (1958). Origins - An etymological dictionary of Modern English. London: Routledge.

RAATH, P. (2002). Soccer through the years, 1862-2002. Cape Town: P. Raath.

RAUTENBACH, T.C. (1995). Die stigting en aanvangsjare van die Universiteit van Port Elizabeth. Ongepubliseerde PhD proefskrif. Port Elizabeth: Universiteit van Port Elizabeth.

TAYLOR, M. (2008). The Association game - A history of British football. London: Pearson.

TRADER, C. (2002). History of the Port Elizabeth Football Association: 1896-2002. Port Elizabeth: Port Elizabeth Football Association.

VAN DER MERWE, F.J.G. (2001). Oorspronklike voetbal aan die Kaap en die ontstaan van die Stellenbosch Rugbyvoetbalklub: Nuwe feite. Suid-Afrikaanse Tydskrif vir Navorsing in Sport, Liggaamlike Opvoedkunde en Ontspanning, 23(1): 85-94.

YOUNG, J. (2006). The spirit of the tower: The Grey, 1856-2006. Port Elizabeth: Grey High School and Grey Junior School.

Dr Lloyd B. Hill: Centre for Culture and Languages in Africa, University of Johannesburg Bunting Road Campus, Johannesburg, Republic of South Africa. Tel.: +27 (0)11 5594259, Fax.: +27 (0)11 5591612, E-mail: lloydhill@sun.ac.za

Since January 2010 based in the Department of Sociology and Social Anthropology at the University of Stellenbosch. Email: 1loydhill@sun.ac.za

(Subject editor: Prof. F.J.G. van der Merwe) 